\title{
DAMPAK PELATIHAN KETERAMPILAN HIDUP (LIFE SKILLS) MONTIR OTOMOTIF TERHADAP KESEMPATAN KERJA DAN PENDAPATAN WARGA BELAJAR
}

\author{
Dayat Hidayat \\ e-mail : dayathidayat194@yahoo.com \\ Pendidikan Luar Sekolah, FKIP Universitas Singaperbangsa Karawang \\ Jalan HS. Ronggowaluyo, Telukjambe Timur, Karawang - Jawa Barat, 41362
}

\begin{abstract}
Abstrak: Tujuan penelitian ini adalah untuk menganalisis pelaksanaan pelatihan keterampilan hidup (life skills) montir otomotif di PKBM Cepat Tepat, yang meliputi tahapan perencanaan, pelaksanaan dan penilaian untuk meningkatkan kesempatan kerja dan pendapatan warga belajar. Pendekatan yang digunakan adalah kualitatif dengan metode studi kasus. Penelitian ini dilaksanakan pada bulan Maret sampai dengan Juni tahun 2013 di PKBM Cepat Tepat Karawang. Teknik pengumpulan data melalui observasi, wawancara dan studi dokumentasi. Subjek yang diteliti yaitu enam orang yang terdiri dari empat orang warga belajar, satu orang pengurus, dan satu orang sumber belajar atau pelatih. Analisis data menggunakan model interaktif, melalui tahapan: (a) koleksi data (data collection), (b) reduksi data (data reductional), (c) penyajian data (data display), dan (d) penarikan kesimpulan/verifikasi (conclusion/verifying). Hasil penelitian menunjukkan bahwa perencanaan pelatihan life skills montir otomotif dimulai dengan analisis kebutuhan belajar calon warga belajar dan daya dukung yang tersedia di PKBM. Pelaksanaan pelatihan berlangsung dengan baik dengan melibatkan seluruh komponen pelatihan keterampilan hidup (life skills) montir otomotif. Hasil pelatihan juga menunjukkan peningkatan keterampilan di bidang otomotif dan sikap kewirausahaan warga belajar secara mandiri. Dampak program pelatihan life skills menunjukkan peningkatan perolehan kesempatan kerja dan pendapatan warga belajar untuk membuka bengkel sendiri atau di bengkel-bengkel otomotif dan perusahaan industri di Kabupaten Karawang.
\end{abstract}

Kata-kata Kunci: pelatihan keterampilan hidup, kesempatan kerja, pendapatan warga belajar

\section{THE IMPACT OF LIFE SKILL TRAINING FOR AUTOMOTIVE MECHANIC IN EMPLOYMENT OPPORTUNITY AND LEARNERS' INCOME}

\begin{abstract}
The purpose of this study was to analyze the implementation of life skills for automotive mechanic in CLC Cepat Tepat, which includes the steps of planning, implementation and assessment to improve employment and learners income. The approach used in this study is qualitative case study method. The data collection techniques through observation, interviews and documentation study. Subjects are six people consisting of four learners, one of organizer, and one of learning resources or trainers. Analysis of data used an interactive model, through the following steps: collection of data, reduction of data, display of data, and conclusion or verification. The results showed that the implementation of life skills training for automotive mechanic started by the analysis of learning needs of learners and carrying capacity which available in the CLC. Life skill training program for automotive mechanic is going well by involving all components of life skills. The results showed that the implementation of life skill training are skill enhancing in the areas of automotive and entrepreneurial attitudes of learners independently. The impact of life skills training program showed an increasing of getting chance to have job and learners' income to open his own workshop or others automotive ones and automotive industry companies in Karawang.
\end{abstract}

Keywords: life skills training, employment, learners' income

\section{PENDAHULUAN}

Seorang pakar pendidikan nonformal Ivan Illich menyarankan untuk mengadakan revolusi belajar dalam masyarakat untuk mendorong perubahan budaya. la menyatakan bahwa upaya untuk mengadakan perubahan yang tambal sulam terhadap komponen dan proses belajar dalam 
pendidikan sekolah yang ada sekarang ini tidak akan menjamin tumbuhnya masyarakat baru yang dapat memecahkan dengan segera masalah-masalah yang dihadapinya. Untuk mengadakan revolusi belajar itu dianjurkan perubahan secara menyeluruh dalam sistem pendidikan yang ada sekarang dengan menyelenggarakan jaringan-jaringan belajar (learning webs) di masyarakat. Program jaringan belajar ini mencakup pertukaran keterampilan dan keahlian, dan mempertemukan peserta didik yang memiliki kebutuhan belajar dengan sumber belajar yang tepat untuk melayaninya. Salah satu program pendidikan nonformal yang diintegrasikan dengan pendidikan formal atau secara utuh program pendidikan nonformal saja yang saat ini sedang dikembangkan adalah pendidikan keterampilan hidup (life skills).

Bertitik tolak dari masalah tersebut di atas, dilakukan konsolidasi agar pendidikan dapat membekali peserta didik dengan keterampilan hidup (life skills). Pendidikan keterampilan hidup (life skills) lebih luas dari sekedar keterampilan bekerja, apalagi sekedar keterampilan manual. Pendidikan keterampilan hidup (life skills) merupakan konsep pendidikan yang bertujuan untuk mempersiapkan peserta didik agar memiliki keberanian dan kemauan menghadapi masalah hidup dan kehidupan secara wajar tanpa merasa tertekan, kemudian secara kreatif menemukan solusi serta mampu mengatasinya. Artinya peserta didik yang telah mengikuti pendidikan keterampilan hidup (life skills) memiliki keterampilan tertentu yang dapat digunakan sebagai keahlian untuk meningkatkan pendapatan ekonomi kehidupannya sesuai dengan minat, bakat, kemampuan, dan sumber daya yang tersedia di lingkungannya. Pendidikan keterampilan hidup (life skills) adalah program pendidikan yang dapat mensinergikan berbagai mata pelajaran menjadi kecakapan hidup, yang diperlukan seseorang, di manapun ia berada, bekerja atau tidak bekerja, apapun profesinya. Dengan bekal keterampilan hidup tersebut diharapkan para lulusan akan mampu memecahkan problema kehidupan yang dihadapi, termasuk mencari atau menciptakan pekerjaan bagi mereka yang tidak melanjutkan.

Untuk dapat mewujudkan pendidikan keterampilan hidup (life skills), perlu diterapkan prinsip pendidikan berbasis luas (broad based education) yang tidak hanya berorientasi pada bidang akademik semata atau vokasional semata, tetapi juga memberikan bekal learning how to learn sekaligus learning to unlearn, tidak hanya belajar teori, tetapi juga mempraktikkannya untuk memecahkan masalah kehidupan sehari-hari. Dengan demikian, secara umum pendidikan keterampilan hidup (life skills) bertujuan untuk mengembalikan pendidikan pada fitrahnya, yaitu mengembangkan potensi peserta didik untuk menghadapi peranannya di masa datang. Secara khusus, pendidikan keterampilan hidup (life skills) bertujuan untuk: (a) mengaktualisasikan potensi peserta didik sehingga dapat digunakan untuk memecahkan masalah yang dihadapi, (b) memberikan kesempatan kepada lembaga pendidikan nonformal untuk mengembangkan pelatihan yang fleksibel sesuai dengan prinsip pendidikan berbasis luas (broad-based education), dan (c) mengoptimalkan pemanfaatan sumberdaya di lingkungan masyarakat, dengan memberi peluang pemanfaatan sumber daya yang ada di masyarakat, sesuai dengan prinsip manajemen berbasis masyarakat (community based management).

Pendidikan keterampilan hidup (life skills) jalur pendidikan nonformal bertujuan meningkatkan pengetahuan, keterampilan, dan sikap warga belajar di bidang tertentu sesuai dengan bakat dan minatnya sehingga memiliki bekal kemampuan untuk bekerja yang dapat mendatangkan penghasilan yang layak guna memenuhi kebutuhan hidupnya. Program pendidikan keterampilan hidup (life skills) bertujuan untuk memberikan pelayanan kepada peserta didik agar (a) memiliki pengetahuan, keterampilan dan sikap yang dibutuhkan dalam memasuki dunia kerja baik bekerja secara mandiri (wirausaha) dan/ atau bekerja pada suatu perusahaan produksi/ jasa dengan penghasilan yang semakin layak untuk memenuhi kebutuhan hidupnya; (b) memiliki motivasi dan etos kerja yang tinggi serta dapat menghasilkan karya-karya yang unggul dan mampu bersaing di pasar global; (c) memiliki kesadaran yang tinggi tentang pentingnya pendidikan untuk dirinya sendiri maupun anggota keluarganya; (d) memiliki kesempatan yang sama untuk memperoleh pendidikan dalam rangka mewujudkan keadilan pendidikan di setiap lapisan masyarakat.

Pendidikan keterampilan hidup (life skills) bermanfaat bagi peserta didik sebagai bekal dalam menghadapi dan memecahkan problema hidup dan kehidupan, baik sebagai pribadi yang mandiri, warga masyarakat dan warga negara. Jika hal itu 
berhasil, maka faktor ketergantungan (dependency factor) akibat banyaknya pengangguran dapat diturunkan, yang berarti produktivitas nasional akan meningkat. Sebagai suatu konsep, pendidikan keterampilan hidup tentu terbuka dan memang akan terus berkembang.

Rumusan tujuan pelatihan keterampilan hidup (life skills) disusun sebagai pedoman utama dalam merancang seluruh kegiatan pelatihan, memilih dan menetapkan aktivitas pembelajaran dalam pelatihan, menyeleksi calon peserta pelatihan, dan menghindari hal-hal yang tidak realistis serta berdampak negatif dalam pelatihan. Tujuan pelatihan memiliki fungsi sebagai berikut : (a) sebagai tolok ukur penilaian, dalam arti bahwa pelatihan dinilai berhasil apabila tujuan yang telah ditentukan dapat tercapai sebagaimana diharapkan, (b) sebagai pemberi arah bagi semua unsur/ komponen pelatihan, khususnya pelatih dan peserta pelatihan, (c) sebagai acuan tentang standar/kriteria untuk merancang kurikulum pelatihan, dan (d) sebagai media komunikasi bagi pelatih (Sudjana, 2007). Dengan demikian, dalam merumuskan tujuan pelatihan, setiap pengurus atau pelaksana pelatihan harus memahami fungsi tujuan pelatihan tersebut sehingga pelatihan dapat dilaksanakan secara efisien dan efektif.

Tujuan pelatihan dapat dijadikan dasar dalam menguraikan persyaratan pekerjaan, memilih metode, media, dan sistem organisasi, mengidentifikasi kebutuhan belajar peserta pelatihan pada sat pelatihan berakhir, menumbuhkan motivasi peserta pelatihan untuk terus belajar, menggambarkan proses belajar yang lebih efisien dan efektif, menyusun standar alat evaluasi hasil belajar yang ajeg (valid) dan dapat dipercaya (reliable). Tujuan pelatihan membantu penilai dan pelatih dalam mengetahui hasil yang seharusnya diperoleh dalam pelatihan, serta mengetahui dampak pelatihan bagi para lulusan bagi kemajuan dirinya, peningkatan kinerja pada lembaga dimana lulusan bertugas, pembelajaran orang lain dan/atau pengaruhnya bagi masyarakat yang menjadi layanan lulusan program pelatihan. Dengan demikian, tujuan pelatihan adalah gambaran perilaku yang diharapkan dapat dicapai oleh peserta pelatihan setelah mengkuti pelatihan. Tujuan ini dipandang sebagai tolok ukur yang akurat pencapaian hasil pelatihan.

Selain peningkatan keterampilan melalui kegiatan pelatihan, faktor yang tidak kalah penting adalah menumbuhkan sikap perilaku kewirausahaan warga belajar sehingga dapat bekerja secara mandiri. Kewirausahaan adalah applying creativity and innovation to slove the problem and to exploit opportunities that people face everyday. Kewirausahaan adalah penerapan kreativitas dan inovasi untuk memecahkan masalah dan upaya memanfaatkan peluang yang dihadapi setiap hari. Kewirausahaan merupakan gabungan dari kreatifitas, inovasi dan keberanian menghadapi risiko yang dilakukan dengan cara kerja keras untuk membentuk dan memelihara usaha baru. Kreativitas diartikan sebagai kemampuan mengembangkan ide-ide baru dan untuk menemukan cara baru untuk memecahkan persoalan dan menghadapi peluang (creativity is the ability to develop new ideas and discover new ways of looking at problem and opportunities) (Zimmerer, 1996).

Selanjutnya, Drucker (1994) berpendapat bahwa kewirausahaan adalah suatu kemampuan untuk menciptakan sesuatu yang baru dan berbeda (ability to create the new and different thing). Bahkan, enterpreneurship secara sederhana sering juga diartikan sebagai prinsip atau kemampuan wirausaha. Kewirausahaan adalah ability to create the new and different, suatu kemampuan untuk menciptakan sesuatu yang baru dan berbeda.

Pada saat kondisi perekonomian negara kita masih belum menentu dan daya beli masyarakat sepertinya cenderung stagnan, karena pengaruh dari krisis ekonomi dan bahkan krisis multidimensial yang berkepanjangan, tetapi kenyataannya keinginan masyarakat untuk memiliki kendaraan bermotor tidak pernah surut, terbukti dengan meningkatnya angka penjualan dari berbagai merk motor dan mobil, bahkan sekarang ini telah muncul puluhan merk-merk motor dan mobil baru yang memperebutkan pasar otomotif di negara Indonesia. Selain itu, kini di kabupaten Karawang, khususnya di Karawang bagian selatan telah berdiri ratusan perusahaan atau pabrik-pabrik yang bergerak di berbagai sektor produksi dan tentunya industri tersebut memerlukan teknisi-teknisi di bidang otomotif yang handal dengan jumlah cukup banyak.

Dengan memperhatikan kondisi masyarakat di Kabupaten Karawang yang telah berkembang menjadi kawasan industri besar, tenaga-tenaga kerja yang mempunyai keterampilan serta keahlian di bidang otomotif keberadaanya sangat diperlukan. 
Dengan meningkatnya kendaraan otomotif di kabupaten Karawang, perusahaan-perusahaan yang bergerak dalam perbengkelan tumbuh dengan pesat. Dampak dari berdirinya industri-industri di Karawang, tentu saja memerlukan tenaga kerja yang banyak pula. Tetapi permasalahannya sekarang kesempatan kerja ini sulit didapatkan oleh masyarakat Karawang sendiri, mereka kalah bersaing dengan tenaga-tenaga kerja yang berasal dari luar Karawang.

Untuk memenangkan persaingan dalam memasuki pasar kerja di bidang industri yang ada di Karawang, maka sumber daya manusia Karawang sendiri perlu ditingkatkan. Mereka harus memiliki keterampilan atau keahlian tertentu sebagaimana yang dipersyaratkan oleh perusahaan-perusahaan atau pasar kerja. Pusat Kegiatan Belajar Masyarakat (PKBM) Cepat Tepat Karawang yang memiliki salah satu program unggulan di bidang pelatihan otomotif merasa tergerak mempersiapkan calon tenaga kerja di bidang otomotif agar diterima di perusahaan atau membuka bengkel otomotif sendiri.

PKBM Cepat Tepat menyelenggarakan pelatihan keterampilan montir otomotif yang bertujuan untuk membekali pengetahuan, sikap dan keterampilan warga belajar untuk meningkatkan kualitas hidupnya melalui peningkatan taraf hidup di bidang ekonomi. Pelatihan keterampilan montir otomotif di PKBM Cepat Tepat Karawang selain didukung oleh berbagai program pelayanan pendidikan nonformal, di dalamnya menggunakan pendekatan mastery learning (belajar tuntas) dan sistem insentif dengan pengendalian dan pembinaan yang sistematik. Pelatihan keterampilan hidup (life skills) montir otomotif ini perlu dikaji dan lebih dikaji secara cermat keunikannya sebagai salah satu model PNF yang memiliki prospek yang baik di masa yang akan datang.

Program pelatihan keterampilan hidup (life skills) montir otomotif di PKBM Cepat Tepat berusaha untuk menjembatani permasalahan yang dihadapi antara sektor industri dan calon tenaga kerja (masyarakat pencari kerja). Dimana saat ini sektor industri mempunyai kebutuhan akan tenaga kerja yang mempunyai keahlian khusus, sedangkan di lain pihak masyarakat pencari kerja, sumber daya manusianya belum sesuai dengan harapan sektor industri. Program pelatihan keterampilan hidup (life skills) montir otomotif di PKBM Cepat Tepat Karawang diselenggarakan untuk mendidik masyarakat usia produktif, terutama warga Karawang yang tergolong miskin dan tidak mempunyai pekerjaan, agar mempunyai keterampilan dan keahlian di bidang otomotif. Setelah selesai diharapkan dapat bekerja di berbagai sektor industri atau bekerja secara mandiri di bidang perbengkelan otomotif untuk meningkatkan taraf hidupnya.

Tujuan pelatihan keterampilan montir otomotif memberikan kerangka acuan dalam penyampaian materi pelatihan baik teori, praktik maupun implementasinya. Tujuan pelatihan disusun untuk meningkatkan efektivitas, produktivitas dan efisiensi proses pelatihan di lembaga pendidikan yang melaksanakan pelatihan. Meningkatkan kualitas hasil pelatihan ditandai oleh semakin banyaknya pencapaian komponen tujuan pelatihan dan semakin tingginya nilai pragmatis materi yang dapat diimplementasikan oleh stakeholders, khususnya peserta pelatihan.

Tujuan pelatihan keterampilan montir otomotif merupakan dasar bagi penentuan langkah-langkah kegiatan dalam mengembangkan komponen dan proses pelatihan itu sendiri. Tujuan pelatihan tersebut merupakan inti dalam sistem pelatihan. Tujuan pelatihan keterampilan montir otomotif di PKBM Cepat Tepat yang dirancang dengan jelas akan mempermudah kegiatan untuk mencapainya karena pelatih dapat melakukan komunikasi yang efektif terhadap peserta pelatihan sehingga terjadi proses pelatihan dengan baik. Tujuan pelatihan yang dirumuskan dengan baik akan memberikan arah untuk menetapkan cara-cara praktis dan objektif dalam menentukan fakta, prinsip, konsep, dan kemampuan khusus sebagai bahan pembelajaran dalam pelatihan termasuk penentuan jenis dan jumlah bahan pembelajaran yang tepat sesuai dengan kebutuhan tujuan pelatihan.

Mengacu kepada kondisi yang telah dikemukakan di atas, pelatihan keterampilan montir otomotif yang bertujuan untuk membekali pengetahuan, sikap dan keterampilan warga belajar untuk meningkatkan kualitas hidupnya melalui peningkatan taraf hidup di bidang ekonomi. Pelatihan keterampilan montir otomotif di PKBM Cepat Tepat Karawang selain didukung oleh berbagai program pelayanan pendidikan nonformal, di dalamnya menggunakan pendekatan mastery learning (belajar tuntas).

Terdapat 50 peserta pelatihan keterampilan montir otomotif di PKBM Cepat Tepat Karawang, 
setelah mengikuti pelatihan, sebanyak $60 \%$ akan disalurkan untuk bekerja di sektor industri dan bengkel-bengkel yang berada di Karawang dan sekitarnya. Sebanyak $40 \%$ difasilitasi untuk membuka usaha sendiri di bidang perbengkelan, yaitu usaha bengkel mobil dan motor. Target yang diharapkan setelah warga belajar mengikuti pelatihan keterampilan montir otomotif di PKBM Cepat Tepat Karawang adalah minimal mampu memperbaiki kerusakan-kerusakan kecil atau besar yang dialami oleh mesin otomotif serta dapat merangkai kembali garda yang terurai, merakit kabel kabel kelistrikan yang ada pada mesin otomotif, dan memasang lampu pada kendaraan otomotif serta keterampilan las listrik dan las karbit.

Berdasarkan latar belakang tersebut, maka fokus masalah dalam penelitian ini adalah bagaimana dampak pelatihan keterampilan hidup (life skills) montir otomotif terhadap kesempatan kerja dan pendapatan warga belajar di PKBM Cepat Tepat Karawang? Penelitian ini bertujuan untuk mengungkapkan dan menganalisis data tentang perencanaan, pelaksanaan, penilaian, hasil dan dampak pelatihan keterampilan hidup (life skills) montir otomotif terhadap kesempatan kerja dan pendapatan warga belajar di PKBM Cepat Tepat Karawang.

\section{METODE PENELITIAN}

Penelitian ini dilakukan menggunakan pendekatan kualitatif. Tujuan penelitian ini ditulis dengan istilah-istilah "teknis" penelitian yang bersumber dari bahasa penelitian kualitatif (Schwandt, 2007 dalam Cresswell, 2013). Alasan penggunaan pendekatan kualitatif adalah karena lebih mudah apabila berhadapan dengan kenyataan, dan menyajikan secara langsung hakikat hubungan antara peneliti dengan responden, lebih peka dan lebih dapat menyesuaikan diri dengan banyak penajaman pengaruh bersama terhadap pola-pola nilai yang dihadapi (Moleong, 2010). Penelitian ini bertujuan menganalisis informasi tentang fenomena utama yang dieksplorasi dalam penelitian, partisipan, dan lokasi penelitian tentang dampak pelatihan keterampilan hidup (life skills) montir otomotif terhadap peningkatan kesempatan kerja dan pendapatan warga belajar di PKBM Cepat Tepat Karawang. Penelitian tentang pelatihan keterampilan montir otomotif dilaksanakan pada bulan Maret sampai dengan Juni tahun 2013 di PKBM Cepat Tepat Karawang.

Metode yang digunakan dalam penelitian ini adalah studi kasus. Metode ini merupakan suatu penelitian kualitatif yang berusaha menemukan makna, menyelidiki proses, dan memperoleh pengertian dan pemahaman yang mendalam dari individu, kelompok dan situasi (Emzir, 2010). Metode penelitian ini bertujuan memperoleh gambaran kasus secara detail, analisis tema atau pokok bahasan, dan interpretasi peneliti atau penegasan kasus. Interpretasi ini dapat disebut "pelajaran yang dipelajari" (Guba \& Lincolin, 1989 dalam Milan J.M. \& Schumacher, 1997). Dalam penelitian ini, dianalisis tentang perencanaan, pelaksanaan, penilaian, hasil dan dampak pelatihan keterampilan hidup (life skills) montir otomotif terhadap peningkatan kesempatan kerja dan pendapatan warga belajar di PKBM Cepat Tepat Karawang. Sebagai sumber informasi, subjek dalam penelitian ini ditentukan secara purposive sampling yang terdiri data dari satu orang pengelola, satu orang tutor dan tiga orang warga belajar pelatihan keterampilan hidup (life skills) montir otomotif di PKBM Cepat Tepat Karawang.

Tahap-tahap yang dilakukan dalam penelitian ini adalah: (1) orientasi untuk mendapatkan informasi tentang apa yang penting untuk ditemukan, (2) eksplorasi untuk menentukan sesuatu secara terfokus, dan (3) member check untuk mengecek temuan menurut prosedur dan memperoleh laporan akhir (Nasution, 1992). Data yang dikumpulkan dalam penelitian ini adalah data kualitatif yang ditunjang pula data kuantitatif. Instrumen yang digunakan dalam mengumpulkan data adalah observasi, wawancara mendalam, dan analisis dokumentasi sebagai sumber data triangulasi yang dapat dipertanggungjawabkan keakuratannya. Teknik pengumpulan data ini digunakan untuk melacak atau membuktikan kebenaran data yang dikumpulkan untuk dianalisis pelatihan keterampilan life skills montir otomotif terhadap peningkatan kesempatan kerja dan pendapatan warga belajar di PKBM Cepat Tepat Karawang.

Teknik analisis data yang digunakan dalam penelitian ini menggunakan model interaktif. Tahap-tahap model ini yaitu: (a) koleksi data (data collection), (b) reduksi data (data reductional), (c) 
penyajian data (data display), dan (d) penarikan kesimpulan/verifikasi (conclusion/verifying). Untuk lebih jelasnya dapat dilihat pada gambar 1 berikut ini.

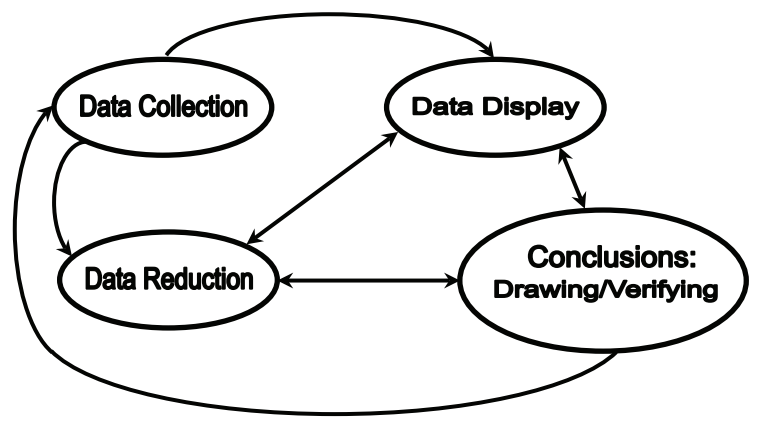

Gambar 1. Komponen analisis data model interaktif menurut Milles M. B. \& Huberman A.M. (1994).

\section{HASIL DAN PEMBAHASAN}

\section{Perencanaan Pelatihan Keterampilan Hidup (Life Skills) Montir Otomotif}

Berdasarkan hasil wawancara dan studi dokumentasi yang diperoleh dari pengurus PKBM Cepat Tepat diperoleh informasi bahwa pelatihan keterampilan hidup (life skills) montir otomotif telah dilaksanakan sesuai dengan pedoman pengurusan program pendidikan keterampilan hidup (life skills) program PNF. Perencanaan program pelatihan keterampilan hidup (life skills) montir otomotif di PKBM Cepat Tepat Karawang dimulai dengan analisis kebutuhan belajar calon warga belajar dan kondisi lingkungan yang disesuaikan dengan daya dukung yang tersedia di PKBM Cepat Tepat tersebut. Maksudnya alasan yang mendasari ketua PKBM Cepat Tepat merencanakan untuk menyelenggarakan program pelatihan keterampilan hidup (life skills) montir otomotif disebabkan karena sekarang ini di kabupaten Karawang, khususnya di bagian selatan telah banyak berdiri ratusan perusahaan atau pabrik-pabrik yang bergerak di bidang industri. Berbagai perusahaan industri tersebut memerlukan teknisi-teknisi di bidang otomotif handal dengan jumlah yang cukup besar. Memperhatikan kondisi tersebut, maka keberadaan tenaga-tenaga kerja yang mempunyai keterampilan dan keahlian di bidang otomotif sangat diperlukan. Selain itu, meningkatnya kendaraan otomotif maka perusahaan-perusahaan yang bergerak di bidang perbengkelan banyak didirikan.

Berasumsi pada kondisi tersebut di atas, maka PKBM Cepat Tepat Karawang yang telah berpengalaman di bidang otomotif tergerak untuk mempersiapkan calon tenaga kerja di bidang otomotif agar diterima di perusahaan yang bergerak di bidang industri atau dapat membuka bengkel otomotif secara mandiri yang sekarang ini keberadaannya sangat dibutuhkan.

Proses perencanaan pelatihan keterampilan hidup (life skills) montir otomotif di PKBM Cepat Tepat dimulai dengan rekrutmen sumber belajar atau instruktur yang memiliki kualifikasi atau keahlian di bidang otomotif. Rekrutmen sumber belajar ini dilakukan sesuai dengan petunjuk pelaksanaan program life skills yang mensyaratkan bahwa pengurus program life skills harus lebih dulu memiliki tenaga pendidik/sumber belajar yang ahli di bidangnya. Setelah itu, pengurus PKBM Cepat Tepat melakukan rekrutmen warga belajar yang tergolong ke dalam usia produktif (16 - 44 tahun), berasal dari keluarga miskin dan sedang menganggur/belum memiliki pekerjaan. Tingkat pendidikan calon warga belajar mulai dari lulusan SD/MI sampai dengan DO SLTA. Persyaratan calon warga belajar tersebut sesuai dengan petunjuk pelaksanaan program life skills, yaitu (a) belum memiliki keterampilan, (b) menganggur atau tidak memiliki pekerjaan, (c) berusia antara $16-44$ tahun, (d) putus sekolah, (e) pendidikan maksimal SLTA/Sederajat, dan (f) sanggup mengikuti ketentuan pelatihan yang telah ditetapkan oleh pengurus.

Pengurus PKBM Cepat Tepat Karawang bekerjasama dengan Dinas Pendidikan Kabupaten selanjutnya menyusun kurikulum pelatihan keterampilan hidup (life skills) montir otomotif yang meliputi (a) tujuan pelatihan, (b) materi pelatihan, (c) pendekatan, metode dan teknik pelatihan yang digunakan, (d) alokasi waktu, (e) evaluasi, dan (f) kriteria keberhasilan yang akan dicapai.

Pada dasarnya, tujuan pelatihan keterampilan 
hidup (life skills) montir otomotif di PKBM Cepat Tepat Karawang seseuai dengan tujuan pengurusan program PNF secara umum seperti yang dikemukakan dalam Peraturan Pemerintah Nomor 73 tahun 1991 tentang Pendidikan Luar Sekolah bab II pasal 2 ayat 2, bahwa "tujuan pendidikan luar sekolah adalah membina warga belajar agar memiliki pengetahuan keterampilan dan sikap yang diperlukan untuk mengembangkan diri, bekerja mencari nafkah, atau melanjutkan pendidikan ke tingkat dan/atau jenjang yang lebih tinggi".

Tujuan program pelatihan keterampilan hidup (life skills) montir otomotif di PKBM Cepat Tepat Karawang adalah membina warga belajar agar memiliki pengetahuan dan keterampilan di bidang otomotif dan sikap kewirausahaan yang diperlukan untuk mengembangkan usaha, sehingga menjadi sarana peningkatan kesempatan kerja dan pendapatan warga belajar.

Pelatihan dapat didefinisikan sebagai pengajaran atau pemberian pengalaman kepada seseorang untuk mengembangkan tingkah laku (pengetahuan, skill/keterampilan dan sikap) agar mencapai sesuatu yang diinginkan (Robinson, 1981:12). Pelatihan merupakan bagian integral dari proses penguatan kelembagaan dalam mempersiapkan pelaku pembangunan (stakeholders) agar mampu berpartisipasi dalam pengelolaan program pembangunan. Kebutuhan suatu model pelatihan yang memberikan suatu pandangan menyeluruh tentang pelatihan menjadi sangat krusial dalam rangka meningkatkan kapasitas lembaga dan sumber daya manusia serta memberikan definisi pelatihan yang ditekankan pada tempat dilaksanakannya pelatihan. Mereka mendefinisikan pelatihan sebagai usaha sistematis untuk menguasai keterampilan, peraturan, konsep ataupun cara berperilaku yang berdampak pada peningkatan kinerja. Misalnya, untuk pelatihan jabatan kerja, setting pelatihan diusahakan semirip mungkin dengan lingkungan kerja yang sebenarnya (Goldstein dan Gressner (1988) dalam Kamil, 2007). Sebagai bagian dari proses pendidikan, pelatihan dilaksanakan melalui tahap perencanaan, pelaksanaan, dan penilaian.

Perencanaan merupakan suatu proses yang terorganisir dan berkesinambungan dari pengidentifikasian unsur-unsur dan aspek-aspek suatu organisasi untuk penentuan keadaan sekarang dari unsur-unsur dan aspek-aspek tersebut serta interaksinya, memproyeksikan unsur-unsur dan aspek-aspek tersebut untuk periode waktu tertentu, serta perumusan dan pemrograman rangkaian tindakan dan rencana untuk mencapai hasil yang diinginkan. Perencanaan adalah suatu kebijakan untuk menggali dan memanfaatkan sumbersumber yang tersedia secara efektif dan efisien untuk mencapai tujuan-tujuan sosio-ekonomi atau sosio-kultural tertentu. Karena itu, perencanaan merupakan fungsi awal dari keseluruhan kegiatan pengelolaan dan merupakan proses sistematis untuk pengambilan keputusan tentang apa yang akan dilaksanakan, mengapa dilaksanakan, tujuan yang ingin dicapai, waktu yang dibutuhkan, bagaimana proses pelaksanaannnya, daya dukung apa yang tersedia, serta berbagai resiko dan kemungkinan hambatan yang akan dihadapi.

Pada hakikatnya, perencanaan merupakan usaha sadar, terorganisasi, dan terus menerus dilakukan untuk memilih alternatif yang terbaik dari sejumlah alternatif tindakan guna mencapai tujuan (Waterson, 1965 dalam Sudjana. D. 2004: 61). Selanjutnya, Schaffer (1970) dalam Sudjana (2004) mengemukakan "Apabila perencanaan dibicarakan, maka kegiatan ini tidak akan terlepas dari hal-hal yang berkaitan dengan proses pengambilan keputusan. Proses pengambilan keputusan tersebut dimulai dari dengan perumusan tujuan, kebijaksanaan, dan sasaran secara luas, yang kemudian berkembang pada tahapan penerapan tujuan dan kebijaksanaan itu dalam rencana yang lebih rinci berbentuk program-program untuk dilaksanakan."

Yehezkel Dror dalam Sudjana (2004) mengemukakan "Planning is process of prepraring a set of dicision for action in the future directed at achieving goals by preferable means". Perencanaan adalah proses untuk mempersiapkan seperangkat keputusan tentang kegiatan-kegiatan pada masa yang akan datang dengan diarahkan pada pencapaian tujuan-tujuan melalui penggunaan sarana yang tersedia.

Demikian pula Friedman dalam Sudjana, D. (2004) mengemukakan "Planning is a process by which a scientific and technical knowledge is joined to organized action". Perencanaan adalah proses menggabungkan pengetahuan ilmiah dan teknik ke dalam kegiatan yang diorganisasi. Dengan demikian, perencanaan merupakan kegiatan awal keseluruhan proses kegiatan suatu organisasi atau lembaga. Termasuk misalnya perencanaan proses pelatihan 
yang akan dilaksanakan oleh suatu lembaga pendidikan.

Pada prinsipnya, perencanaan memiliki fungsi: (a) untuk mengurangi adanya hambatan-hambatan dan pemborosan sehingga semua yang tercakup di dalamnya dapat dimanfaatkan sebaik mungkin, (b) sebagai pelayanan yang berupa prosedur di dalam proses pencapaian tujuan, dan (c) sebagai penyeimbang daripada komponen-komponen yang terlibat di dalamnya. Perencanaan merupakan bagian awal dari manajemen. Perencanaan merupakan faktor yang sangat mendasar dan menentukan keberhasilan pencapaian tujuan pelatihan. Tanpa adanya perencanaan yang jelas dan terukur kita tidak akan mengetahui dengan pasti, apakah proses pelatihan yang dilaksanakan berhasil atau tidak.

Perencanaan pelatihan yang menyeluruh mengandung efektivitas dan efisiensi sistem dan proses, yang mencerminkan komponen-komponen yang secara sistematis saling berhubungan dan saling mempengaruhi. Komponen-komponen tersebut meliputi: (a) alasan mengapa pelatihan dilaksanakan, (b) tujuan pelatihan yang akan dicapai, (c) tindakan yang akan dilaksanakan untuk mencapai tujuan pelatihan tersebut, (d) daya dukung yang tersedia, baik manusia maupun nonmanusia, (e) bagaimana proses pelatihan tersebut dilaksanakan, dan (f) waktu yang dibutuhkan untuk melaksanakan pelatihan tersebut.

Dengan demikian dapat disimpulkan bahwa perencanaan pelatihan merupakan suatu proses yang sistematis dalam pengambilan keputusan tentang tindakan yang akan dilakukan pada waktu yang akan datang untuk mencapai tujuan pelatihan yang telah ditetapkan. Disebut sistematis karena perencanaan itu digunakan dengan menggunakan prinsip-prinsip tertentu. Prinsip-prinsip tersebut mencakup proses pengambilan keputusan, penggunaan pengetahuan dan teknik secara ilmiah, serta tindakan atau kegiatan yang terorganisasi.

Pentingnya aspek perencanaan dalam pelatihan keterampilan montir otomotif di PKBM Cepat Tepat ini sejalan dengan hasil penelitian yang dilakukan Sutisna dan Trisnamansyah (2010) yang menyatakan bahwa tahap perencanaan pelatihan, dilakukan melalui identifikasi kebutuhan belajar. Hasil identifikasi adalah berupa materi pelatihan yang berdimensi. Pertama, yang pengetahuan meliputi: (a) pemahaman karakteristik warga belajar, (b) penguasaan konsep dan landasan pendidikan, (c) pemahaman perencanaan pembelajaran, (d) pelaksanaan pembelajaran beserta metode dan teknik, dan (e) evaluasi dalam pembelajaran. Kebutuhan materi dalam dimensi keterampilan, meliputi: (a) penyusunan program pembelajaran dan silabus, (b) penyusunan persiapan pelaksanaan pembelajaran, (c) pelaksanaan pembelajaran, dan (d) evaluasi pembelajaran. Kedua, identifikasi peserta pelatihan. Ketiga, identifikasi sumber belajar sebagai fasilitator. Keempat, identifikasi bahan ajar yang digunakan, yaitu bahan ajar yang dikemas sendiri oleh narasumber/peneliti dan bersifat praktis dalam pelatihan.

Hasil penelitian ini menunjukkan kesamaan bahwa perencanaan pelatihan keterampilan montir otomotif di PKBM Cepat Tepat dilaksanakan melalui tahapan identifikasi kebutuhan belajar, peserta pelatihan, dan materi sesuai dengan perkembangan bidang otomotif yang semakin pesat di Kabupaten Karawang.

\section{Pelaksanaan Pelatihan Keterampilan Hidup (Life Skills) Montir Otomotif}

Pelatihan keterampilan hidup (life skills) montir otomotif di PKBM Cepat Tepat dilakukan untuk membangkitkan dan meningkatkan budaya belajar sebagai bagian dari aktivitas belajar sendiri sehingga tercipta warga belajar yang memiliki pengetahuan dan keterampilan di bidang otomotif serta sikap kewirausahaan yang mendukung pengembangan usaha warga belajar yang berdampak pada peningkatan kesempatan kerja dan pendapatan kehidupannya.

Untuk mencapai tujuan pelatihan keterampilan hidup (life skills) montir otomotif di PKBM Cepat Tepat diciptakan kondisi pelatihan yang memungkinkan warga belajar dapat belajar secara optimal dan instruktur bergairah untuk memberikan materi pelatihan. Dalam pelatihan keterampilan hidup (life skills) montir otomotif di PKBM Cepat Tepat Karawang melibatkan beberapa komponen pelatihan sebagai berikut.

Pertama, masukan sarana (instrumental input) yang meliputi keseluruhan sumber dan fasilitas yang memungkinan bagi seseorang atau kelompok dapat melakukan kegiatan belajar. Masukan sarana yang terlibat dalam proses pelatihan program life skills montir otomotif di PKBM Cepat Tepat meliputi: (a) kurikulum yang berisi materi pelatihan otomotif yang bertujuan untuk memberi bekal pengetahuan dan keterampilan di bidang motor bensin, suspensi, 
kelistrikan, dan keselamatan kerja, dan memberi kemampuan kewirausahaan seperti sikap percaya diri, berorientasi pada tugas dan hasil, berani dan mampu mengambil resiko, sikap kepepimpinan, keorisinilan, serta berorientasi ke masa depan untuk memasuki dunia kerja atau berusaha secara mandiri membuka lapangan kerja; (b) pendekatan yang digunakan adalah partisipatif. Pendekatan ini bertujuan untuk memberikan kesempatan seluas-luasnya kepada peserta didik untuk terlibat dalam perencanaan, pelaksanaan, dan penilaian pelatihan. Pada pendekatan ini, sumber belajar berfungsi untuk memfasilitasi peserta didik dalam melakukan kegiatan pelatihan montir otomotif; (c) metode yang digunakan dalam pelatihan program life skills montir otomotif ini adalah kelompok. Warga belajar dibagi dalam kelompok besar (50 orang) ketika memperoleh materi teori otomotif dan kewirausahaan dan kelompok kecil yang terdiri dari 5 orang pada saat mempraktekkan materi pelatihan yang diberikan sumber belajar, dan (d) Teknik pelatihan yang digunakan dalam pelatihan keterampilan hidup (life skills) montir otomotif, antara lain ceramah, tanya jawab, demontrasi, penugasan (drill), kerja kelompok, dan praktik lapangan. Media yang digunakan adalah buku-buku sumber otomotif, OHP, gambar dan alat peraga.

Kedua, masukan mentah (raw input), yaitu peserta didik (warga belajar) dengan berbagai karakteristik yang dimilikinya. Warga belajar program pelatihan keterampilan hidup (life skills) montir otomotif di PKBM Cepat Tepat adalah 50 orang warga belajar yang memiliki karateristik: (a) belum memiliki pengetahuan dan keterampilan di bidang otomotif; (b) menganggur atau tidak memiliki pekerjaan tetap (miskin), lemah dalam investasi dan menabung; (c) berusia antara 26 - 44 tahun; (d) putus sekolah (DO SD/SLTP/SLTA); (e) berpendidikan maksimal SLTA; dan (f) sanggup mengikuti ketentuan pelatihan yang telah ditetapkan pengurus.

Ketiga, masukan lingkungan (environmental input) yaitu faktor lingkungan yang menunjang atau mendorong berjalannya proses pelatihan life skills montir otomotif yang meliputi (a) kondisi lingkungan keluarga yang mendorong warga belajar aktif mengikuti proses pelatihan montir otomotif, dan (b) kondisi lingkungan belajar seperti ruangan, media belajar, dan iklim belajar yang mendukung proses pelatihan montir otomotif.

Keempat, proses pelatihan yang menyangkut interaksi antara masukan sarana, terutama pendidik dengan masukan mentah, yaitu warga belajar program pelatihan keterampilan hidup (life skills) montir otomotif. Proses pelatihan keterampilan hidup (life skills) montir otomotif ini terdiri atas: (a) kegiatan belajar-membelajarkan, bimbingan dan pelatihan yang dilakukan oleh sumber belajar dengan melibatkan komponen masukan sarana, masukan mentah, dan masukan lingkungan; serta (b) penilaian pelatihan keterampilan hidup (life skills) montir otomotif di PKBM Cepat Tepat Karawang yang dilaksanakan masing-masing sumber belajar di akhir pemberian materi pelatihan baik teori maupun praktek. Penilaian secara menyeluruh proses pelatihan keterampilan hidup (life skills) montir otomotif dilakukan oleh pihak pengurus yang bekerja sama dengan Dinas Pendidikan Kabupaten dan Dinas Tenaga Kerja Kabupaten. Penilaian program pelatihan keterampilan hidup (life skills) montir otomotif yang difokuskan pada proses pelatihan selama kegiatan berlangsung, yang meliputi kemampuan sumber belajar dalam menyampaikan materi, kemampuan warga belajar menerima pengetahuan otomotif, sikap kewirausahaan dan keterampilan mempraktekkan materi. Dengan demikian, aspek yang dievaluasi dalam pelatihan keterampilan hidup (life skills) montir otomotif di PKBM Cepat Tepat Karawang ini meliputi (a) penilaian kognitif, (b) afektif, dan (c) psikomotor.

Kelima, keluaran (output) yaitu kuantitas lulusan dan kualitas perubahan tingkah laku yang didapat melalui proses pelatihan keterampilan hidup (life skills) montir otomotif. Perubahan tingkah laku ini mencakup ranah kognitif, afektif, dan psikomotor yang sesuai dengan kebutuhan belajar yang mereka perlukan. Standar kompetensi pengetahuan, sikap, dan keterampilan yang harus dimiliki oleh warga belajar program pelatihan keterampilan hidup (life skills) montir otomotif tersebut yaitu: (a) warga belajar minimal mampu memperbaiki kerusakankerusakan kecil atau besar yang dialami oleh mesin otomotif serta dapat merangkai kembali garda yang terurai, merakit kabel-kabel kelistrikan yang ada pada mesin otomotif, dan memasang lampu-lampu pada kendaraan otomotif serta keterampilan las listrik juga las karbit; (b) dapat melakukan pemeliharaan kendaraan harian secara berkala; (c) dapat mengatasi dan memperbaiki kerusakan secara sederhana; (d) dapat melakukan bongkar pasang mesin mobil atau motor; (e) dapat 
menggunakan alat-alat ukur yang diperlukan dalam pekerjaan yang bersangkutan; (f) mengerti akan persyaratan keselamatan kerja dalam melakukan pekerjaan; dan (g) memiliki sikap kewirausahaan dalam mengembangkan pekerjaannya.

Keenam, masukan lain (other input) adalah daya dukung lain yang memungkinkan para peserta didik dan lulusan dapat menggunakan kemampuan yang telah dimiliki untuk kemajuan kehidupannya setelah mengikuti proses pelatihan montir otomotif, meliputi: (a) dana yang diberikan kepada pengurus untuk menyelenggarakan program pelatihan keterampilan hidup (life skills) montir otomotif di PKBM Cepat Tepat, (b) kondisi lapangan kerja yang mendukung lulusan setelah mengikuti proses pelatihan keterampilan hidup (life skills) montir otomotif, dan (c) kemitraan yang mendukung lulusan dapat segera bekerja setelah mengikuti proses pelatihan montir otomotif.

Ketujuh, pengaruh atau dampak (impact) yang menyangkut hasil yang telah dicapai oleh warga belajar setelah mengikuti program pelatihan keterampilan hidup (life skills) montir otomotif di PKBM Cepat Tepat Karawang. Dampak yang diharapkan setelah warga belajar mengikuti proses pelatihan keterampilan hidup (life skills) montir otomotif di PKBM Cepat Tepat Tepat Karawang ini adalah: (a) perubahan taraf hidup yang ditandai dengan perolehan kesempatan pekerjaan atau berwirausaha di bidang otomotif sebagai montir, perolehan atau peningkatan pendapatan, kesehatan, dan penampilan diri, dan (b) kegiatan membelajarkan orang lain atau mengikutsertakan orang lain dalam memanfaatkan hasil yang telah dimiliki.

Sebagai proses, pelatihan merupakan suatu kegiatan berlangsungnya kegiatan belajar. Kegiatan belajar termasuk pelatihan, pertama-tama dimulai dari diri seseorang sehingga orang itu melakukan proses belajar. Belajar merupakan suatu kegiatan yang bertujuan untuk mengembangkan diri melalui proses penyesuaian tingkah laku. Penyesuaian tingkah laku yang terwujud karena belajar, bukan akibat langsung dari pertumbuhan orang yang belajar itu. la melakukan kegiatan belajar dengan menyesuaikan tingkah lakunya dalam upaya untuk meningkatkan kualitas kehidupannya.

Secara etimologi, pelatihan merupakan terjemahan dari kata "training" dalam bahasa Inggris. Secara harfiah akar kata "training" adalah "train", yang berarti: (1) memberi pelajaran dan praktik (give teaching and practice), (2) menjadikan berkembang dalam arah yang dikehendaki (cause to grow in a required direction), (3) persiapan (preparation), dan (4) praktik (practice).

Noe, Hollenbeck, Gerhart and Wright (2003:251) mengemukakan bahwa training is a planned effort to facilitate the learning of job-related knowledge, skills, and behavior by employe. Artinya, pelatihan merupakan suatu usaha yang terencana untuk memfasilitasi pembelajaran tentang pekerjaan yang berkaitan dengan pengetahuan, keahlian dan perilaku oleh pegawai. Pelatihan formal yang direncanakan secara matang dan mempunyai suatu format pelatihan yang terstruktur. Dalam meningkatkan dan mengembangkan sumber daya manusia, berbagai pelatihan banyak dilaksanakan dalam masyarakat atau dalam dunia kerja untuk mengisi kebutuhan-kebutuhan fungsional. Kegiatankegiatan pelatihan ini sangat populer dan mudah dilakukan karena menggunakan prinsip-prinsip dan metode-metode pendidikan dan pembelajaran pada pendidikan luar sekolah. Meskipun demikian dalam banyak kasus pula pelaksanaan pelatihan ini tidak jarang dipadukan atau saling melengkapi dengan pendidikan formal.

Ditinjau dari filsafat ilmunya, bahwa fenomena kehadiran program pelatihan dapat memunculkan tiga pertanyaan: (a) dari segi ontologis, apakah yang dimaksud pelatihan, (b) dari segi axiologis, apakah sesungguhnya manfaat pelatihan, dan (c) dari segi epistimologis, bagaimana cara mengkaji dan mengembangkan pelatihan?. Lebih khusus lagi, dari sudut pandang pendidikan, berkembangnya program pelatihan dapat mengundang beberapa pertanyaan antara lain (a) apakah perbedaan antara pendidikan dan pelatihan, (b) di manakah posisi pelatihan dan pendidikan apabila keduanya saling berkaitan (Sudjana, 2007). Secara ontologis, pengertian pelatihan telah dirumuskan oleh para ahli, yaitu "Training is a process used by organizations to meet their goals. It is called into operation when a discrepancy is perceived between the current situation and a preferred state of affairs. The trainer's role is to facilitate trainee's movement from the status qou toward the ideal" (Friedman dan Yarbrough, 1985 dalam Sudjana, 2007).

Berkaitan dengan proses pelatihan, Sudjana (2004) memberikan formula pembelajaran (termasuk kegiatan pelatihan) yang dapat dirumuskan sebagai berikut : $P b=f P(m S x y z)$. "Pembelajaran 
adalah fungsi (f) untuk membelajarkan (m) peserta didik (S) terhadap materi pelatihan (x) untuk mencapai hasil belajar (y) yang menimbulkan pengaruh belajar (z)". Berdasarkan rumus formula pembelajaran tersebut dapat diketahui bahwa fungsi pembelajaran adalah untuk membantu, membimbing, melatih, memelihara, merawat, menumbuhkan, mendorong, membentuk, meluruskan, menilai, dan mengembangkan kemampuan peserta didik, baik pengetahuan, keterampilan serta sikap yang menimbulkan pengaruh positif bagi hidup dan penghidupan peserta didik.

Pelaksanaan suatu kegiatan pembelajaran, termasuk pelatihan merupakan proses transformasi pengetahuan, sikap dan keterampilan dari sumber belajar kepada warga belajar. Pelaksanaan pelatihan keterampilan hidup (life skills) montir otomotif di PKBM Cepat Tepat Karawang tidak terlepas dari kurikulum yang telah ditetapkan, yang meliputi tujuan pelatihan yaitu memberikan pengetahuan dan keterampilan di bidang otomotif serta sikap kewirausahaan yang mendukung pengembangan usaha warga belajar.

Secara epistimologis, kajian tentang pelatihan dapat dilihat dalam pengembangan sistem, model dan pengelolaan pelatihan. Dari segi sistem dapat dipahami bahwa pada umumnya pelatihan memiliki masukan (input), proses dan keluaran (output) (Sudjana, 2007). Hasil penelitian di lapangan menunjukkan bahwa pelaksanaan pelatihan keterampilan hidup (life skills) montir otomotif di PKBM Cepat Tepat Karawang merupakan proses interaksi edukatif antara warga belajar dengan komponen-komponen pembelajaran lainnya, seperti masukan sarana, masukan lingkungan, dan masukan lain. Oleh karena pelatihan merupakan satuan pendidikan luar sekolah maka sesuai dengan sistem pendidikannya, pelatihan memiliki unsur-unsur yang terdiri atas komponen, proses, dan tujuan.

Komponen pelatihan mencakup masukan lingkungan (environmental input), masukan sarana (instrumental input), masukan mentah, (raw input), dan masukan lain (other input). Proses (processes) pelatihan merupakan interaksi pembelajaran antara masukan sarana, terutama pelatih, dengan masukan mentah yaitu peserta pelatihan. Tujuan pelatihan terdiri atas tujuan pembelajaran antara keluaran (output), dan tujuan pembelajaran akhir yaitu pengaruh (outcome). Pengaruh berkaitan dengan menfaat atau kegunaan pelatihan yang telah diikuti peserta pelatihan bagi dirinya, lembaga, masyarakat, dan lain sebagainya. Singkatnya, program pelatihan akan berhubungan erat dengan unsur-unsur pelatihan yang disusun secara sistemik, yaitu memuat komponen, proses dan tujuan pelatihan.

Proses pelatihan yang berlangsung melibatkan tujuh komponen. Pertama, masukan sarana (instrumental input) meliputi keseluruhan sumber dan fasilitas yang memungkinan bagi seseorang atau kelompok dapat melakukan kegiatan belajar. Kedua, masukan mentah (raw input) yaitu peserta didik (warga belajar) dengan berbagai karakteristiknya yang dimilikinya. Ketiga, masukan lingkungan (environmental input), yaitu faktor lingkungan yang menunjang atau mendorong berjalannya program pendidikan. Keempat, proses yang menyangkut interaksi antara masukan sarana, terutama pendidik dengan masukan mentah, yaitu peserta didik (warga belajar). Kelima, keluaran (output), yaitu kuantitas lulusan yang disertai dengan kualitas perubahan tingkah laku yang didapat melalui kegiatan belajarmembelajarkan. Keenam, masukan lain (other input) adalah daya dukung lain yang memungkinkan para peserta didik dan lulusan dapat menggunakan kemampuan yang telah dimiliki untuk kemajuan kehidupannya. Ketujuh, pengaruh (impact) yang menyangkut hasil yang telah dicapai oleh peserta didik dan lulusan (Sudjana, 2004) .

Tujuan pelatihan lebih mengenalkan tingkah laku baru atau mengubah tingkah laku yang ada sehingga tercipta tingkah laku yang baru (Nadler, 1982). Pelatihan dirancang untuk memperbaiki performa peserta didik. Pelatihan cenderung tertuju pada tujuan-tujuan yang spesifik seperti menjalankan mesin dan mengikuti aturan-aturan baru (Glaser, 1962) .

Pelatihan jenis apapun sebenarnya tertuju pada dua sasaran, yaitu partisipasi dan organisasi. Melalui pelatihan, diharapkan terjadi perbaikan tingkah laku pada partisipan pelatihan yang sebenarnya merupakan anggota suatu organisasi. Perbaikan organisasi itu sendiri agar menjadi lebih efektif. Apabila pelatihan tertuju pada karyawan perusahaan atau pabrik, tujuan pelatihan adalah agar individu karyawan tersebut menjadi lebih baik pengetahuan, keterampilan, dan sikapnya, selanjutnya perusahaan/pabrik menjadi lebih baik pula, misalnya lebih produktif. Pada pelatihan kader organisasi, misalnya, pelatihan bertujuan 
memperbaiki kecakapan kader dan selanjutnya diharapkan organisasinya lebih efektif dalam melaksanakan program-programnya dan mencapai tujuannya. Untuk jelasnya, dapat dilihat diagram pada gambar 2 berikut ini

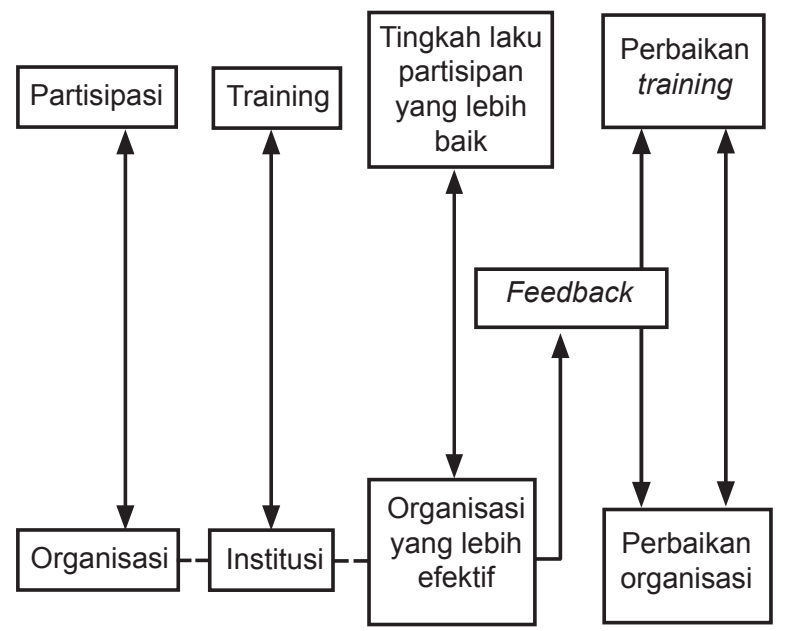

Gambar 2. Diagram proses pelatihan (Marzuki, 2009)

Pada Gambar 2, dikemukakan bahwa pelatihan merupakan variabel antara untuk mengubah variabel bebas partisipan dan organisasi menjadi sesuatu yang lebih baik, yaitu kemampuan individu dan keefektifan organisasi. Dale S. Beach (1975) dalam Kamil, M. (2007:10) mengemukakan, "The objective of training is to achieve a change inthe behavior of those trained" (tujuan pelatihan adalah untuk memperoleh perubahan dalam tingkah laku mereka yang dilatih). Sementara itu dari pengertian pelatihan yang dikemukakan Flippo, E.B. (1994) secara lebih rinci tampak bahwa tujuan pelatihan adalah untuk menigkatkan pengetahuan dan keterampilan seseorang.

Keberhasilan suatu program pelatihan lebih banyak dinilai dari segi sejauhmana perubahan perilaku yang diharapkan terjadi pada peserta didik atau Iulusan pelatihan sebagai hasil dari proses pelatihan. Keberhasilan pelatihan pada umumnya dalam tujuan pelatihan itu sendiri. Tujuan pelatihan tidak hanya utuk meningkatkan pengetahuan dan keterampilan saja, melainkan juga untuk mengembangkan bakat.

Marzuki, S. (2009:12) mengemukakan ada tiga tujuan pokok pelatihan, yaitu: (1) memenuhi kebutuhan organisasi, (2) memperoleh pengertian dan pemahaman yang lengkap tentang pekerjaan dengan standar dan kecepatan yang telah ditetapkan dan dalam keadaan yang normal serta aman, dan
(3) membantu para pemimpin organisasi dalam melaksanakan tugasnya.

Selanjutnya Sudjana, D. (2007: 104) mengemukakan bahwa tujuan pelatihan pada dasarnya adalah suatu sebagai pernyataan yang menguraikan suatu perubahan yang diusulkan akan terjadi pada diri peserta pelatihan, yaitu perubahan setelah peserta pelatihan menyelesaikan pengalaman belajarnya dalam pelatihan. Lebih lengkap tujuan pelatihan dapat diberi arti sebagai suatu rumusan tentang hasil yaitu keluaran (output) dan dampak (outcome) yang ingin dicapai oleh pelatihan. Mengacu pada pengertian tersebut, maka dapat dikemukakan bahwa tujuan pelatihan adalah gambaran tentang perilaku yang diharapkan dapat dicapai oleh peserta pelatihan setelah mengkuti pelatihan. Tujuan ini dipandang sebagai tolok ukur yang akurat untuk pencapaian hasil suatu pelatihan. Tujuan dapat berbentuk verbal (lisan) dan.atau nonverbal (tulisan). Tujuan secara tertulis secara jelas lebih baik dan mudah dipahami oleh peserta pelatihan dibandingkan dengan tujuan lisan.

\section{Hasil Pelatihan Keterampilan Hidup (Life skills) Montir Otomotif}

Berdasarkan hasil pengamatan dan wawancara dengan terhadap empat orang lulusan pelatihan pendidikan keterampilan (life skills) montir otomotif di PKBM Cepat Tepat Karawang diperoleh informasi bahwa mereka telah memiliki pengetahuan di bidang otomotif dan sikap kewirausahaan, serta telah memiliki keterampilan untuk memperbaiki kendaraan bermotor. Dalam kaitan dengan pelatihan keterampilan montir otomotif di PKBM Cepat Tepat Karawang, perubahan disposisi atau kemampuan yang telah diperoleh warga belajar adalah perubahan pengetahuan dan keterampilan di bidang otomotif dan sikap kewirausahaan untuk mengembangkan usaha di bidang otomotif.

Secara rinci hasil pelatihan yang telah diperoleh warga belajar setelah mengikuti pelatihan keterampilan hidup (life skills) montir otomotif di PKBM Cepat Tepat Karawang, baik yang berkaitan dengan perubahan pengetahuan, sikap, dan keterampilan, gambaran dari seorang responden yang mengemukakan:

Saya setelah mengikuti pelatihan keterampilan hidup (life skills) montir otomotif di PKBM Cepat Tepat Karawang telah memiliki pengetahuan tentang motor bensin, suspensi yang meliputi seperti chasis otomotif, badan otomotif, kerja bangku, pemeliharaan dan perbaikan gangguan, ilmu bahan 
dan perkakas, serta gambar teknik, kelistrikan, keselamatan kerja, dan ilmu kewirausahaan yang berkaitan dengan kepercayaan diri, sikap berorientasi pada tugas dan hasil, berani mengambil risiko dalam mengembangkan usaha, sikap kepemimpinan, dan sikap kreatif.

Saya percaya dapat mengembangkan usaha di bidang perbengkelan. Saya yakin bahwa keterampilan otomotif yang dimilikinya dapat dijadikan mata pencaharian yang menjanjikan. Sebagai seorang montir motor, saya kini sudah berani membuka bengkel sendiri walaupun dalam skala kecil. Saya selalu tekun, teliti, dan sabar pada saat bekerja agar kendaraan bermotor yang diperbaikinya tidak membahayakan konsumennya. saya selalu berusaha untuk bersikap ramah dan jujur kepada konsumennya. Saya selalu bekerja dengan keras, inovatif dan kreatif dalam mengembangkan keterampilannya di bidang bengkel otomotif. Pekerjaan ini dijalani dengan rasa senang, karena dia merasa yakin bahwa usaha bengkelnya dapat berkembang karena berlokasi di jalan protokol yang banyak dilalui kendaraan bermotor jalur Karawang - Bekasi.

Saya sudah terampil menurunkan dan menaikan mesin motor dari kendaraan, bongkar pasang kepala silinder berbagai tipe motor, bongkar pasang piston, bongkar pasang mekanisme katup, bongkar pasang pada sistem pendingin, bongkar pasang pompa bensin mekanik dan sistem listrik, bongkar pasang karburator berbagai tipe motor, melepas dan memasang kembali tangki bahan bakar, bongkar pasang manipol atau exhaust, bongkar pasang poros engkol, bongkar pasang pompa minyak pelumas dan saringan kendaraan motor. Selain itu, saya sudah terampil dalam memeriksa baterai, bongkar pasang dinamo, bongkar pasang motor stater, bongkar pasang distributor, memeriksa dan memasang busi motir, memasang sistem penerangan dan sistem perlengkapan kendaraan motor.

Dari hasil analisis data menunjukkan hasil pelatihan keterampilan hidup (life skills) montir otomotif di PKBM Cepat Tepat Karawang berdasarkan ranah kognitif, afektif, dan keterampilannya, dapat diuraikan pada gambar 3 berikut.

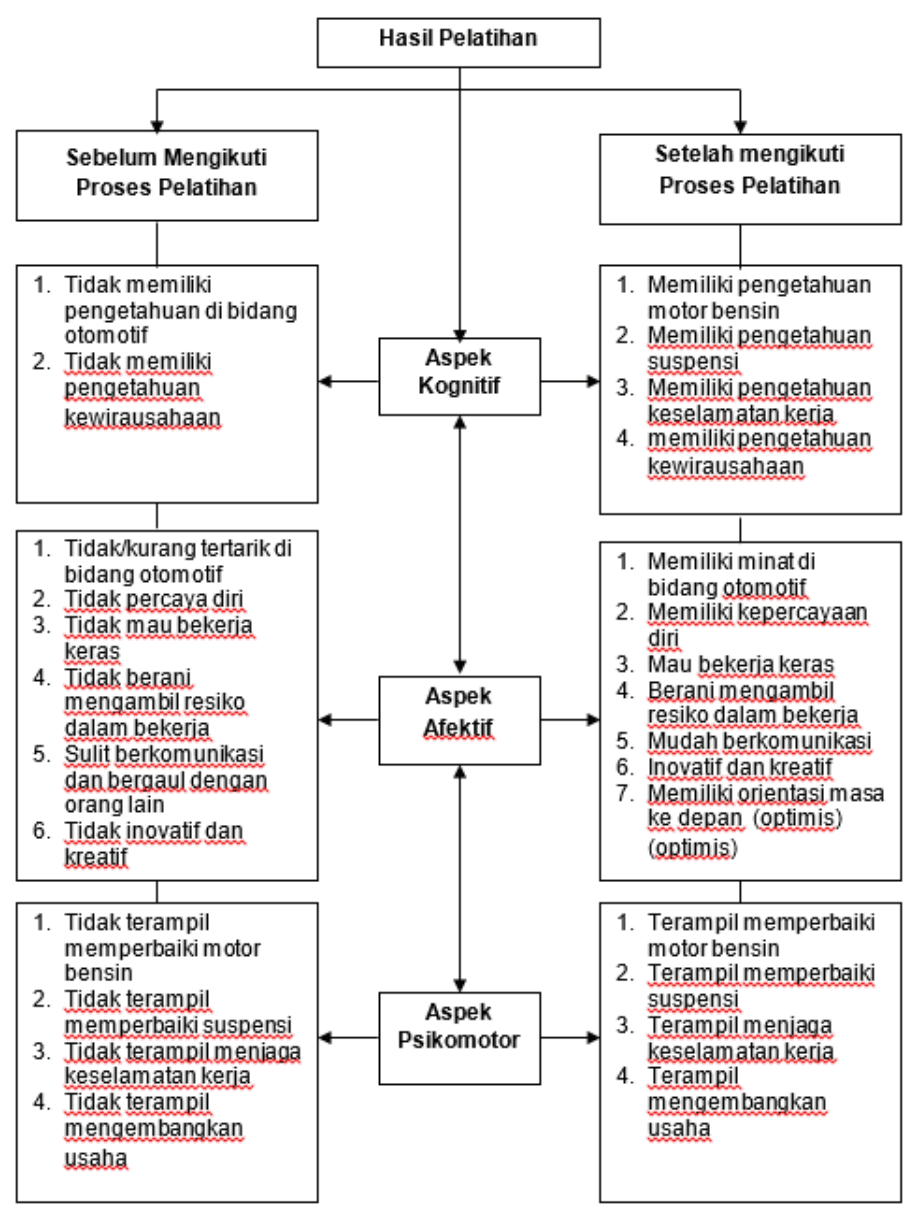

Gambar 3. Perubahan hasil belajar sebelum dan setelah mengikuti pelatihan keterampilan montir otomotif di PKBM Cepat Tepat Karawang (Sumber: Hasil Analisis Data) 
Dari gambaran hasil penelitian yang telah dikemukakan dapat diketahui bahwa pelatihan keterampilan hidup (life skills) montir otomotif di PKBM Cepat Tepat Karawang, telah memberikan dampak terhadap perubahan kehidupan warga belajar. Warga belajar mengalami peningkatan pengetahuan dan keterampilan di bidang otomotif dan mengalami perkembangan sikap kewirausahaan yang bermanfaat dalam mengembangkan usaha di bidang perbengkelan.

Hasil pelatihan merupakan kriteria keberhasilan atau target yang telah dicapai dalam suatu proses pembelajaran. Hasil pembelajaran merupakan produk penyesuaian tingkah yang diperoleh warga belajar. Travers, J. (1972) dalam Sudjana, D. (2004) mengemukakan bahwa belajar adalah suatu proses yang menghasilkan penyesuaian tingkah laku. Belajar sebagai hasil adalah akibat wajar dari proses, atau proses menyebabkan hasil.

Seperti telah dikemukakan di atas tentang pengertian pelatihan, Dearden (1984) dalam Kamil, M. (2007:7), menyatakan pula bahwa pelatihan pada dasarnya meliputi proses belajar mengajar dan latihan bertujuan untuk mencapai tingkatan kompetensi tertentu atau efisiensi kerja. Sebagai hasil pelatihan, peserta diharapkan mampu merespon dengan tepat dan sesuai situasi tertentu. Seringkali pelatihan dimaksudkan untuk memperbaiki kinerja yang langsung berhubungan dengan situasinya. Dearden lebih memilih menggunakan konsep kompetensi (competences) dibandingkan kinerja (performance). Dia membatasi konsep tersebut untuk tujuan mempersiapkan peserta untuk bertindak berdasarkan situasi-situasi yang biasanya terjadi, serta menerapkannya pada saat melakukan tanggung jawab pekerjaan, baik beban kerja yang lebih kompleks maupun yang lebih sederhana.

Berkaitan dengan pelatihan sebagai hasil, Bloom., B. (1965) dalam Sudjana, D. (2004: 99-102) menyusun klasifikasi tujuan pendidikan (taxonomy of educational objectives) yang meliputi tiga ketegori, yaitu: pertama, ranah kognitif yang mencakup pengetahuan (knowledge), pengertian (comprehension), penerapan (application), analisis, sintesis, dan evaluasi. Kedua, ranah afektif yang mencakup perubahan yang berhubungan minat, sikap, nilai-nilai, penghargaan dan penyesuaian diri. Ketiga, ranah keterampilan yang mencakup keterampilan produktif (productive skills), keterampilan teknik (technical skills), keterampilan fisik (physical skills), keterampilan sosial (social skills), keterampilan pengelolaan (managerial skills), dan keterampilan intelek (intellectual skills).

Berkaitan dengan hasil proses pembelajaran, termasuk kegiatan pelatihan yang memberi makna pada diri warga belajar, Sudjana, D. (2004 : 102) berpendapat sebagai sebagai berikut: "Belajar sebagai hasil bermakna sebagai suatu kemampuan yang dicapai seseorang setelah melalui kegiatan belajar atau sesudah mengalami belajar sebagai proses. Melalui kegiatan belajar sebagai proses, seseorang dapat berpikir, merasakan dan bertindak di dalam dan terhadap kehidupannya. Dengan demikian, belajar sebagai hasil adalah perubahan tingkah laku seseorang melalui proses belajar dan yang harus dan dapat digunakan untuk meningkatkan penampilan dirinya dalam hidup dan kehidupannya."

Dengan demikian, hasil pelatihan adalah perubahan tingkah laku seseorang melalui proses belajar dan yang harus dan dapat digunakan untuk meningkatkan penampilan dirinya dalam hidup dan kehidupannya. Secara umum, manfaat pendidikan yang berorientasi pada keterampilan hidup (life skills) montir otomotif bagi warga belajar adalah memberikan bekal untuk menghadapi dan memecahkan masalah hidup dan kehidupan, baik sebagai pribadi, warga masyarakat dan warga negara yang mandiri. Keberhasilan program life skills diharapkan meningkatkan kesempatan sehingga dapat mengurangi pengangguran, dan meningkatkan produktivitas kerja warga belajar untuk meningkatkan pendapatannya.

Berkaitan dengan hasil pelatihan keterampilan hidup (life skills) montir otomotif di PKBM Cepat Tepat Karawang, menunjukkan sikap kewirausahaan yang mulai tumbuh dan berkembang. Kewirausahaan, menurut Winarto (2004:2-3) dikemukakan bahwa "Entrepreneurship (kewirausahaan) adalah suatu proses melakukan sesuatu yang baru dan berbeda dengan tujuan menciptakan kemakmuran bagi individu dan memberi nilai tambah pada masyarakat." Adapun Hisrich-Peters (1995:10) dalam Alma, B. (2007:26) mengemukakan bahwa "Enterpreneurship is the process of creating something different with value by devoting the necessary time and effort, assuming the accompanying financial, psyhic, and social risk, and receiving the resulting rewards of monetary and 
personal satisfaction and independence". Artinya, kewirausahaan adalah proses menciptakan sesuatu yang lain dengan menggunakan waktu dan kegiatan disertai modal dan resiko serta menerima balas jasa dan kepuasan serta kebebasan).

Selanjutnya, Suryana (2007:10) juga mengemukakan bahwa kewirausahaan merupakan terjemahan dari "entrepreneurship", yang dapat diartikan sebagai "the backbone of economy", yaitu syaraf pusat perekonomian atau sebagai 'tailbone of economy', yaitu pengendali perekonomian suatu bangsa. Secara etimologi kewirausahaan merupakan nilai yang diperlukan untuk memulai suatu usaha (start-up phase) atau suatu proses dalam mengerjakan suatu yang baru (creative) dan sesuatu yang berbeda (innovative).

Pengembangan model pendidikan kewirausahaan telah banyak dilaksanakan untuk meningkatkan kemandirian usaha warga belajar. Hasil penelitian pengembangan model pendidikan kewirausahaan dari Usman, H., Prasaja, L.D. dan Sunarta (2012) menyimpulkan bahwa (a) model pendidikan kewirausahaan meliputi sistem, struktur program pelatihan, komposisi antara teori dengan praktik, modul pelatihan, kriteria peserta, pelatih, metode, dan evaluasi pelatihan; (b) modul-modul hasil pengembangan model layak digunakan untuk pendidikan kewirausahaan guna mengurangi kemiskinan dan pengangguran; dan (c) program pendidikan kewirausaahaan terlaksana dengan sukses.

Lebih lanjut, hasil penelitian Widodo, S. dan Nugroho T.R.D.A. (2014) menyimpulkan bahwa model pendidikan kewirausahaan bagi santri dilakukan untuk menumbuhkan dan meningkatkan karakteristik kewirausahaan santri. Model pendidikan kewirausahaan disusun berdasarkan baseline karakteristik jiwa kewirausahaan santri. Pendidikan kewirausahaan ditujukan pada tiga aspek, yaitu meningkatkan jiwa kewirausahaan, keahlian keterampilan teknis, dan manajemen wirausaha. Keterampilan teknis mengacu pada hasil studi potensi yang ada di sekitar pondok pesantren. Pada implementasinya, pendidikan kewirausahaan perlu juga mengakomodasi perkembangan teknologi. Salah satunya industri kreatif yang perkembangannya dari tahun ke tahun semakin pesat.

Penelitian ini sejalan dengan penelitian tentang pelatihan keterampilan montir otomotif di PKBM Cepat Tepat Karawang dalam meningkatkan keterampilan warga belajar sesuai dengan perkembangan industri otomotif yang semakin pesat dari tahun ke tahun di Kabupaten Karawang. Dampak Pelatihan Keterampilan Hidup (Life Skills) Montir Otomotif

Dari hasil analisis data menunjukkan bahwa dampak yang diperoleh warga belajar setelah mengikuti pelatihan keterampilan hidup (life skills) montir otomotif di PKBM Cepat Karawang adalah terbukanya kesempatan yang memberi pengaruh terhadap peningkatan pendapatan warga belajar. Warga belajar sebelum mengikuti pelatihan keterampilan hidup (life skills) montir otomotif tidak memiliki pekerjaan. Kini warga belajar sudah memiliki pekerjaan yang sesuai dengan pengetahuan dan keterampilannya di bidang otomotif. Dampak yang telah dirasakan warga belajar setelah mengikuti program pelatihan keterampilan hidup (life skills) montir otomotif di PKBM Cepat Tepat.

Sebelum mengikuti program pelatihan keterampilan hidup (life skills) montir otomotif, warga belajar tidak memiliki penghasilan sehingga dalam memenuhi kebutuhan keluarganya masih dibantu oleh orangtua dan mertuanya. Setelah mengikuti program pelatihan keterampilan hidup (life skills) montir otomotif, kini warga belajar dapat membuka bengkel sendiri walaupun belum terlalu besar. Namun baginya, kondisi tersebut merupakan kesempatan kerja yang sangat menjanjikan untuk terus dikembangkan. Pada masa krisis ekonomi di mana setiap orang sangat sulit memperoleh pekerjaan, warga belajar merasa bangga dan senang karena telah memiliki kesempatan kerja yang cukup baik sebagai montir kendaraan bermotor yang didirikannya sendiri. Kini warga belajar tidak tidak lagi bergantung kepada orangtuanya untuk menghidupi kebutuhan keluarganya. Warga belajar memperoleh pendapatan dalam sehari biasanya kurang lebih antara 100.000 sampai dengan 200.000 rupiah. Walaupun penghasilannya tidak menentu, tetapi telah dapat memberi kesempatan kerja dan memperoleh pendapatan. Dari pendapatannya tersebut sebagian kecil ditabung untuk mengembangkan usaha bengkelnya menjadi lebih besar.

Secara keseluruhan dampak peningkatan kesempatan kerja dan pendapatan warga belajar setelah mengikuti pelatihan keterampilan hidup (life skills) montir otomotif di PKBM Cepat Karawang secara umum digambarkan dalam tabel berikut ini. 
Tabel 1. Analisis Data Kesempatan Kerja dan Peningkatan Pendapatan Warga Belajar Sebelum dan Setelah Mengikuti Pelatihan Keterampilan (Life Skills) Montir Otomotif

\begin{tabular}{cllcc}
\hline No & \multicolumn{1}{c}{$\begin{array}{c}\text { Sebelum Mengikuti } \\
\text { Pelatihan }\end{array}$} & \multicolumn{1}{c}{$\begin{array}{c}\text { Setelah Mengikuti } \\
\text { Pelatihan }\end{array}$} & $\begin{array}{c}\text { Jumlah Warga Belajar } \\
\text { (orang) }\end{array}$ & $\begin{array}{c}\text { Persentase } \\
(\%)\end{array}$ \\
\hline 1 & $\begin{array}{l}\text { Tidak bekerja dan tidak } \\
\text { memiliki pendapatan }\end{array}$ & $\begin{array}{l}\text { Bekerja dan memiliki } \\
\text { pendapatan }\end{array}$ & 38 & 76,00 \\
2 & $\begin{array}{l}\text { Tidak bekerja dan tidak } \\
\text { memiliki pendapatan }\end{array}$ & $\begin{array}{l}\text { Belum bekerja dan belum } \\
\text { memiliki pendapatan }\end{array}$ & 12 & 24,00 \\
\hline \multicolumn{2}{r}{ Total } & 50 & 100 \\
\hline
\end{tabular}

Sumber: Hasil Penelitian

Dari data pada Tabel $1 \mathrm{di}$ atas dapat dilihat bahwa warga belajar yang telah bekerja sebagai montir otomotif setelah mengikuti pelatihan keterampilan hidup (life skills) montir otomotif di PKBM Cepat Tepat Karawang sebanyak 34 orang atau sebesar $72 \%$. Dari profesi sebagai montir otomotif tersebut, mereka memperoleh pendapatan. Sisanya sebanyak 12 orang atau sebesar $24 \%$ belum bekerja dan belum memiliki pendapatan.

Dampak merupakan pengaruh kuat yang mendatangkan akibat, baik negatif positif terhadap kehidupan seseorang. Dampak positif yang diharapkan warga belajar setelah memperoleh pengetahuan, sikap dan keterampilan tentang otomotif di PKBM Cepat Tepat Karawang adalah terbukanya kesempatan kerja sehingga dapat meningkatkan pendapatan kehidupannya.

Sudjana (2004) mengemukakan bahwa dampak adalah merupakan tingkat pencapaian tujuan dan sasaran pelatihan. Tujuan umum pelatihan pada dasarnya menjadi arahan utama bagi pengurus program dan merupakan tolok ukur keberhasilan program pelatihan itu. Tujuan tersebut biasanya dirumuskan secara umum, menyeluruh, abstrak dan menggunakan kata kerja intransitif. Adapun tujuan khusus pada dasarnya dititikberatkan pada perubahan tingkah laku warga belajar yang menyangkut pengetahuan, keterampilan, sikap dan nilai yang berkaitan dengan kompetensi yang harus dimiliki oleh peserta selama dan setelah mengikuti proses pelatihan. Tujuan khusus dinyatakan secara rinci, konkret, perubahan tingkah lakunya dapat diukur dan diobservasi, dan dirumuskan dengan menggunakan kata kerja transitif.

Lebih lanjut, Sudjana (2004) mengemukakan bahwa pengaruh (impact) yang menyangkut hasil yang telah dicapai oleh peserta didik dan lulusan setelah melakukan proses pelatihan. Pengaruh ini meliputi: (1) perubahan taraf hidup yang ditandai dengan perolehan pekerjaan, atau berwirausaha, perolehan atau peningkatan pendapatan, kesehatan, dan penampilan diri; (2) kegiatan membelajarkan orang lain atau mengikutsertakan orang lain dalam memanfaatkan hasil yang telah ia miliki, dan (3) peningkatan partisipasinya dalam kegiatan sosial dan pembangunan masyarakat, baik partisipasi buah pikiran, tenaga, harta benda, dan dana.

\section{PENUTUP}

\section{Kesimpulan}

Berdasarkan hasil dan pembahasan penelitian yang telah diuraikan maka dapat disimpulkan sebagai berikut.

Pertama, perencanaan pelatihan program life skills montir otomotif diawali dengan analisis kebutuhan lapangan pekerjaan calon warga belajar yang dilakukan oleh ketua pengurus PKBM Cepat Tepat. Langkah awal perencanaan pelatihan program life skills montir otomotif adalah rekuritmen sumber belajar yang ahli di bidang otomotif dan calon warga belajar tidak memiliki keterampilan dan belum bekerja (menganggur). Warga belajar yang mengikuti pelatihan keterampilan hidup (life skills) montir otomotif berasal dari latar pendidikan yang berbeda. Dalam melakukan rekruitmen warga belajar, ketua pengurus melakukan kerja dengan beberapa instansi yang terkait seperti kepala desa/ lurah, ketua PKBM lainnya atau lulusan kursus montir otomotif PKBM Cepat Tepat Karawang. Selanjutnya, ketua PKBM dengan sumber belajar menyusun kurikulum pelatihan otomotif sebagai program utama dan kewirausahaan sebagai program pendukung. Kurikulum pelatihan montir otomotif bertujuan untuk meningkatkan pengetahuan dan keterampilannya di bidang otomotif serta memiliki 
sikap kewirausahaan untuk mengembangkan usahanya di bidang perbengkelan.

Kedua, pelaksanaan program pelatihan keterampilan hidup (life skills) montir otomotif di PKBM Cepat Tepat Karawang yang dilaksanakan selama 4 bulan berlangsung sesuai dengan tujuan yang telah ditetapkan. Proses pelatihan yang menggunakan pendekatan partisipatif, metode individual dan kelompok, serta teknik yang bervariasi dapat dilaksanakan dengan baik. Kondisi ini ditandai dengan tingginya minat dan motivasi sumber belajar dan warga belajar yang sangat kooperatif selama proses pelatihan berlangsung. Untuk mengukur tingkat pengetahuan, sikap, dan keterampilan warga belajar pengurus melakukan evaluasi, baik yang dilakukan oleh sumber belajar maupun pihak lain seperti Dinas Pendidikan Kabupaten dan Dinas Tenaga Kerja Kabupaten Karawang.

Ketiga, program pelatihan keterampilan hidup (life skills) montir otomotif di PKBM Cepat Tepat telah menunjukkan hasil yang cukup baik. Warga belajar yang mengikuti pelatihan montir otomotif menunjukkan adanya peningkatan pengetahuan dan keterampilan di bidang otomotif yang cukup baik. Demikian pula dengan pengetahuan dan sikap kewirausahaan yang diperoleh warga belajar menunjukkan adanya peningkatan, terutama mereka yang memiliki latar pendidikan SLTP dan SLTA. Kondisi ini ditunjukkan oleh adanya peningkatan pengetahuan dan keterampilan warga belajar dalam memperbaiki kendaraan bermotor dan menjaga keselamatan pada saat bekerja. Warga belajar yang telah bekerja, terutama di bengkel-bengkel otomotif menunjukkan kinerja yang cukup baik. Warga belajar lebih rajin, tekun, teliti, ulet, dan sabar menjalankan pekerjaannya sebagai montir otomotif.

Keempat, dampak yang telah dirasakan oleh warga belajar setalah mengikuti program pelatihan keterampilan hidup (life skills) montir otomotif di PKBM Cepat Tepat Karawang adalah meningkatkan kesempatan kerja, baik di bengkel-bengkel otomotif maupun di perusahaan-perusahaan industri. Sebelumnya warga belajar yang tidak bekerja (mengganggur), kini dapat bekerja sebagai montir motor dan mobil di beberapa bengkel otomotif. Meningkatkanya kesempatan kerja yang dimiliki warga belajar setelah mengikuti program pelatihan keterampilan hidup (life skills) montir otomotif tersebut memberikan dampak terhadap peningkatan pendapatan warga belajar yang sebelumnya tidak memiliki penghasilan. Pendapatan tersebut digunakan untuk memenuhi kebutuhan hidupnya sehari-hari. Selain itu, sebagian dari pendapatan yang telah diperoleh ditabung oleh mereka, baik untuk bekal melanjutkan pendidikan maupun mengembangkan usaha di bidang perbengkelan otomotif.

\section{Saran}

Berdasarkan kesimpulan penelitian tentang program pelatihan keterampilan hidup (life skills) montir otomotif di PKBM Cepat Tepat Karawang, berikut ini dikemukakan beberapa rekomendasi yang dapat dijadikan sebagai bahan pertimbangan dan masukan bagi pihak pengurus PKBM. Rekomendasi tersebut antara lain adalah sebagai berikut.

Pertama, dalam perencanaan pelatihan montir otomotif perlu diperhatikan kemampuan keterampilan awal warga belajar sehingga metode pelatihan yang digunakan lebih menekankan pada individual. Dengan metode individual ini, proses pelatihan montir otomotif dapat lebih memperhatikan tahap-tahap pencapaian peningkatan kemampuan pengetahuan, sikap kewirausahaan dan keterampilam yang harus dikuasai warga belajar.

Kedua, dalam pelaksanaan pelatihan montir otomotif, penggunaan metode, penentuan waktu dan tempat pelatihan disesuaikan dengan keragaman kebutuhan kemampuan warga belajar dan lokasi tempat tinggal warga belajar.

Ketiga, dalam penilaian pelatihan montir otomotif, pengurus PKBM Cepat Tepat memberikan kesempatan belajar bagi warga belajar untuk menentukan sendiri peningkatan pengetahuan, sikap kewirausahaan dan keterampilannya di bidang otomotif sesuai dengan perkembangan teknologi otomotif yang berkembangn semakin pesat.

Keempat, untuk memperoleh dampak pelatihan montir otomotif yang lebih maksimal, pengurus PKBM Cepat Tepat bekerjasama dengan pihak-pihak lain seperti bengkel-bengkel otomotif, perusahaan-perusahaan industri maupun instansi pemerintah maupun swasta sehingga dapat memperluas kesempatan kerja bagi lulusan yang belum bekerja. Warga belajar dapat membentuk kemitraan sebagai sarana perkumpulan untuk mendiskusikan dan bertukar pikiran pengalaman tentang perkembangan dan peningkatan pengetahuan, sikap dan keterampilan yang mereka miliki di bidang otomotif.

Kelima, selain itu, pengurus PKBM Cepat 
Tepat membantu memberikan akses fasilitas permodalan bagi lulusan pelatihan montir otomotif yang ingin membuka bengkel otomotif secara mandiri. Dalam hal ini pengurus dapat memberikan permodalan sendiri maupun menfasilitasi warga belajar yang ingin memperoleh bantuan permodalan dari pihak bank dengan jaminan dari pengurus PKBM.

\section{DAFTAR PUSTAKA}

Alma, B. (2007). Kewirausahaan. Bandung: Alfabeta. Cresswell, J.W. (2013). Research Design. Yogyakarta: Pustaka Pelajar.

Drucker, P. F. (1994). Innovation and entrepreneurship, practice and principle. New York: Harper Business.

Emzir. (2010). Metodelogi penelitian kualitatif: Analisis data. Jakarta: Raja Grasindo.

Flippo, E. B. (1994). Personal management. New York: McGraw Hill Book Company Inc.

Glaser, R. (1962). Training research and education, (ed). Pittsbrugh: University of Pittsbrugh Press.

Kamil, M. (2007). Model pendidikan dan pelatihan: Konsep dan aplikasi. Bandung: Alfabeta.

Marzuki, S. (2009). Pendidikan dan pelatihan. Bandung: Alfabeta.

Milles, M. B., \& Huberman, A. M. (1994). Analisis data kualitatif. Jakarta: Universitas Indonesia Press.

Moleong, L. J. (2010). Metodologi penelitian kualitatif. Bandung: PT. Remaja Rosdakarya.

Milan, J. M., \& Schumacher, S. (1997). Research in education. New York: Addison Wesley Longman. Inc.

Nasution, S. (1992). Metode penelitian naturalistik kualitatif. Bandung: Tarsito.

Nadler, L. (1982). Designing training programs: The critical events model. Philippines: AddisonWesley Publishing Company, Inc.

Noe, Hollenbeck, Gerhart, Wright, (2003). Human resource management, international edition. New York: The McGraw-hill Companies, Inc.

Robinson, K. P. (1981). A handbook of training management. London: Kogan Page Ltd.
Sudjana, D. (2004). Pendidikan nonformal, wawasan, sejarah perkembangan, falsafah, teori pendukung, Azas. Bandung: Falah Production.

Sudjana, D. (2004). Strategi kegiatan belajar mengajar dalam pendidikan nonformal. Bandung: Falah Production.

Sudjana, D. (2004). Manajemen program pendidikan, untuk pendidikan nonformal, dan pengembangan sumber daya manusia. Bandung: Falah Production.

Sudjana, D. (2007). Sistem dan manajemen pelatihan: Teori dan praktek. Bandung: Falah Production.

Sutisna, A.,\& Trisnamansyah, S. (2010). Model pelatihan berbasis kinerja dalam meningkatkan kompetensi tutor pendidikan kesetaraan. Jurnal Cakrawala Pendidikan, 29 (3), 365-378.

Suryana. (2007). Kewirausahaan, pedoman praktis kiat dan proses menuju sukses. Jakarta: Salemba Empat.

Usman, H., Prasaja, L.D.,\& Sunarta. (2012). Model diklat kewirausahaan bagi remaja putus sekolah. Jurnal Cakrawala Pendidikan, 31 (1), 55-66.

Widodo, S.,\& Nugroho. T.R.D.A. (2014). Model pendidikan kewirausahaan bagi santri untuk mengatasi pengangguran di pedesaan. Jurnal Mimbar. 30 (2), 171-179.

Winarto, P. (2004). First step to be an entrepreneur. Jakarta: Alex Media Komputindo.

Zimmerer, T.W.,\& Scarborrough, N.M. (2008). Kewirausahaan dan manajemen usaha kecil. Jakarta : Salemba Empat. 